\title{
Alpha and beta cell evaluation in patients with thalassaemia intermedia and iron overload
}

\author{
V. De Sanctis, M.R. Gamberini, L. Borgatti, G. Atti, C. Vullo and B. Bagni \\ Thalassaemia Centre of the Department of Paediatrics and Medical Physic, Arcispedale S. Anna-U.S.L.n.31, \\ Ferrara, Italy
}

\begin{abstract}
Summary: Insulin and glucagon secretion were studied during an oral glucose tolerance test and arginine infusion in 11 patients with thalassaemia intermedia, who showed laboratory evidence of iron overload. Mean blood glucose concentrations in patients with thalassaemia intermedia were significantly higher than normal and 3 of 11 patients had impaired glucose tolerance. The principal abnormality appears to be a deficiency in insulin and glucagon from the pancreas in response to oral glucose tolerance and arginine stimulation tests. Several factors, such as iron overload, chronic hypoxia, zinc deficiency and increased catecholamine production secondary to anaemia, might play a part in the pathogenesis of these abnormalities. Each of these factors affect individual cases to a varied degree. Our data emphasize the mildness of carbohydrate defect as compared to the degree of insulinopenia and indicate the necessity for prescribing measures which prevent excessive iron deposition and improve iron excretion in thalassaemic patients with iron overload.
\end{abstract}

\section{Introduction}

In milder forms of $\beta$ thalassaemia called 'thalassaemia intermedia', in which regular transfusions are not usually necessary, total iron overload of a magnitude similar to that in transfusion-dependent $\beta$ thalassaemia homozygotes may be found (Pippard et al., 1979), presumably due to increased intestinal iron absorption (Weatherall \& Clegg, 1972; De Alarcon et al., 1979). Iron overload is known to cause cardiac, hepatic and endocrine lesions (Ellis et al., 1954; Flynn et al., 1976; Lassman et al., 1974; De Sanctis et al., 1980; Sabato et al., 1983).

Diabetes or impaired glucose tolerance have been found in patients with $\beta$ thalassaemia major (Costin $e t$ al., 1977; Saudek et al., 1977; Atti et al., 1983). This study was undertaken to evaluate carbohydrate tolerance in relation to alpha and beta cell function in a series of patients with thalassaemia intermedia, who showed laboratory evidence of marked iron overload.

\section{Patients and methods}

Eleven patients, 19-45 years old (mean age 27 y), 6 males and 5 females with raised serum ferritin levels, attending the Centro della Microcitemia of Ferrara,

Correspondence: Professor C. Vullo M.D.

Accepted: 21 June 1985 were chosen to participate in the study (Table I). All patients were in good general health at the time of the study. The diagnosis of thalassaemia intermedia was made on the basis of clinical and laboratory data (Weatherall \& Clegg, 1972). Haemoglobin concentrations ranged between $5.5-9.5 \mathrm{~g} / \mathrm{dl}$. Seven of the patients had received occasional blood transfusions in the past. Liver function was assessed by serum pyruvic transaminase (SGPT). No patient received drugs before the study. Pertinent data are shown in Table I. The control group included eleven subjects, 19-32 years old (mean age 23y), 5 males and 6 females in good health and without family history of diabetes. Informed consent was obtained from all patients. Patients and control subjects were tested between 08.00 and $09.00 \mathrm{~h}$, following an overnight fast. Venous samples were obtained from an indwelling catheter in a superficial arm vein. Patency was maintained by means of a slow infusion of isotonic saline.

An oral glucose tolerance test (OGTT) was performed after 3 days of normocaloric diet. Each subject was given $1.75 \mathrm{~g}$ of glucose per kilogram of weight up to a maximum of $100 \mathrm{~g}$, after an overnight fast of $12-13 \mathrm{~h}$. Venous blood samples were obtained at 0,30 , $60,90,120,180 \mathrm{~min}$ for determination of glucose and immunoreactive insulin. Whole blood glucose concentration was corrected by the formula of Dillon \& Mawr (1965) to the normal haematocrit for age. The

(C) The Fellowship of Postgraduate Medicine, 1985 
Table I Clinical and laboratory data in 11 patients with thalassaemia intermedia

\begin{tabular}{|c|c|c|c|c|c|c|c|c|c|c|}
\hline $\begin{array}{l}\text { Patient } \\
\text { no. }\end{array}$ & $\begin{array}{c}\text { Age } \\
\text { (y./months) }\end{array}$ & Sex & $\begin{array}{c}\text { Weight } \\
\text { (kg) }\end{array}$ & $\begin{array}{c}\text { Height } \\
\text { (cm) }\end{array}$ & $\begin{array}{c}\text { Family history } \\
\text { of diabetes }\end{array}$ & $\begin{array}{c}H b \\
(g / d l)\end{array}$ & $\begin{array}{l}\text { Number of } \\
\text { transfusions }\end{array}$ & Splenectomy & $\begin{array}{c}\text { Ferritin } \\
(n g / m l) \dagger\end{array}$ & $\begin{array}{c}S G P T \\
(m U / \\
m l) \ddagger\end{array}$ \\
\hline 1. & 19.11 & $\mathbf{F}$ & 43.3 & 154.5 & no & 6.2 & 8 & no & 1100 & 10 \\
\hline 2. & 21.2 & $\mathbf{M}$ & 60.4 & 162 & yes & 9.5 & 0 & no & 761 & 77 \\
\hline 3. & 21.5 & $\mathbf{M}$ & 54.7 & 162 & no & 8.5 & 40 & yes & 960 & 51 \\
\hline 4. & 25.6 & $\mathbf{M}$ & 41.8 & 170.5 & no & 7 & 20 & yes & 590 & 35 \\
\hline 5. & 27.8 & $\mathbf{F}$ & 53.8 & 165.1 & no & 6.5 & 21 & yes & 3100 & 50 \\
\hline 6. & 28.7 & $\mathbf{F}$ & 46 & 155.5 & yes & 8.8 & 48 & no & 780 & 37 \\
\hline 7. & 29 & $\mathbf{M}$ & 48.8 & 164.3 & no & 7.8 & 0 & no & 600 & 17 \\
\hline 8. & 29.6 & $\mathbf{M}$ & 58 & 181 & no & 8.4 & 0 & yes & 5000 & 32 \\
\hline 9. & 30.4 & $\mathbf{M}$ & 69 & 184.2 & no & 5.5 & 0 & no & 2280 & 50 \\
\hline 10. & 30.7 & $\mathrm{~F}$ & 60 & 170.4 & no & 6 & 7 & yes & 2950 & 34 \\
\hline 11. & 45.4 & F & 45.4 & 156.2 & no & 8.9 & 40 & no & 826 & 26 \\
\hline
\end{tabular}

$* 1$ transfusion $=350 \mathrm{ml}$ of whole blood; †normal values - males $(n=55) 108 \pm 68 \mathrm{ng} / \mathrm{ml}$, females $(n=33) 32 \pm 25 \mathrm{ng} / \mathrm{ml}$; $\ddagger$ normal values $=<40 \mathrm{mU} / \mathrm{ml}$.

criteria of the WHO Expert Committee on Diabetes Mellitus were used for evaluation of glucose tolerance (Editorial, British Medical Journal, 1980).

For arginine stimulation (ATT) arginine monohydrocloride was administered intravenously in $10 \%$ buffered saline solution at a dose of $0.5 \mathrm{~g} / \mathrm{kg}$ of weight, $\max 25 \mathrm{~g}$, over 30 minutes. Blood samples were taken before and 30, 60, 90 and $120 \mathrm{~min}$ after the end of arginine infusion for glucagon determination.

The concentrations of glucose in the blood (BG) were assayed using the glucose-oxidase enzymatic method (Fibel-Boehringer Test).

Plasma immunoreactive insulin (IRI) was estimated by radioimmunoassay using commercial kits (Dow Lepetit - Milan). Blood samples were collected into glass tubes containing EDTA and immediately centrifuged. The plasma was separated and kept frozen at $-20^{\circ} \mathrm{C}$ for future analysis. All samples were tested in duplicate and values expressed in $\mu \mathrm{IU} / \mathrm{ml}$.

Plasma glucagon levels (IRG) were assayed using commercial kits (Biodata - Milan). Blood samples for glucagon estimation were placed in chilled tubes containing EDTA and trasylol (1.2 mg of EDTA and $500 \mathrm{U}$ of trasylol per $\mathrm{ml}$ of blood) and were immediately centrifuged and plasma stored at $-20^{\circ} \mathrm{C}$. All samples were processed in triplicate and the values were expressed in pmol/1. The intra-assay variability was $10 \%$ and the inter-assay variability $12 \%$. The lower detection limit of the method was $52.2 \mathrm{pmol} / 1$.

To analyse the glucose, insulin and glucagon data, we report the values at each sampling time and the sum of all test values represent the total response ( $\Sigma$ BG, $\Sigma$ IRI, $\mathbf{\Sigma}$ IRG, respectively).

Serum ferritin was assayed by means of a kit (Ramco Laboratories, Houston, Texas) at a serum dilution of $1: 1000$.
The statistical analysis of the results was carried out by the Student's $t$-test and by calculating their correlation coefficient.

\section{Results}

Mean fasting blood glucose concentrations were not significantly different in patients with thalassaemia intermedia compared with normal but following OGTT levels were significantly higher in the thalassaemic group at 30,60,90 and $120 \mathrm{~min}$ (Table II, Figure 1). Three of 11 thalassaemic patients had impaired glucose tolerance (Table I: nos. 1, 3, 5).

The mean plasma insulin concentrations were not

Table II Mean ( \pm s.d.) blood glucose (BG) and plasma insulin values (IRI) before and during oral glucose tolerance test in patients with thalassaemia intermedia and in control subjects

\begin{tabular}{|c|c|c|c|c|}
\hline & \multicolumn{2}{|c|}{$B G(\mathrm{mmol} / \mathrm{l})$} & \multicolumn{2}{|c|}{$I R I(\mu I U / m l)$} \\
\hline $\begin{array}{l}\text { Time } \\
\text { (min) }\end{array}$ & $\begin{array}{l}\text { Thalassaemics } \\
\quad(n=11)\end{array}$ & $\begin{array}{l}\text { Controls } \\
(n=11)\end{array}$ & $\begin{array}{l}\text { Thalassaemics } \\
\quad(n=11)\end{array}$ & $\begin{array}{l}\text { Controls } \\
(n=11)\end{array}$ \\
\hline 1 & $4.8 \pm 0.9$ & $4.7 \pm 0.4$ & $6.6 \pm 7.1$ & $7 \pm 3.3$ \\
\hline 30 & $7.8 \pm 1.3^{* *}$ & $6.6 \pm 1.1$ & $22.3 \pm 15^{* *}$ & $46.2 \pm 25.3$ \\
\hline 60 & $8 \pm 1.3^{* * *}$ & $5.3 \pm 1$ & $23.7 \pm 19.6^{*}$ & $37 \pm 17.6$ \\
\hline 90 & $7.3 \pm 1.4^{* * *}$ & $4.9 \pm 0.9$ & $23.3 \pm 18^{*}$ & $35.2 \pm 12.2$ \\
\hline 120 & $6.9 \pm 1.1^{* * *}$ & $4.7 \pm 1$ & $18.8 \pm 15.3$ & $24.1 \pm 12.2$ \\
\hline 180 & $5 \pm 1.3$ & $4.3 \pm 0.8$ & $11.9 \pm 10$ & $10.7 \pm 7.7$ \\
\hline
\end{tabular}

Conversion: SI to traditional units $=$ glucose $1 \mathrm{mmol} / \mathrm{l}=$ $18 \mathrm{mg} / 100 \mathrm{ml}$

${ }^{*}=P<0.05 ;{ }^{* *} P<0.01 ;{ }^{* * *} \mathrm{P}<0.001$ for the difference $v s$ the controls. 

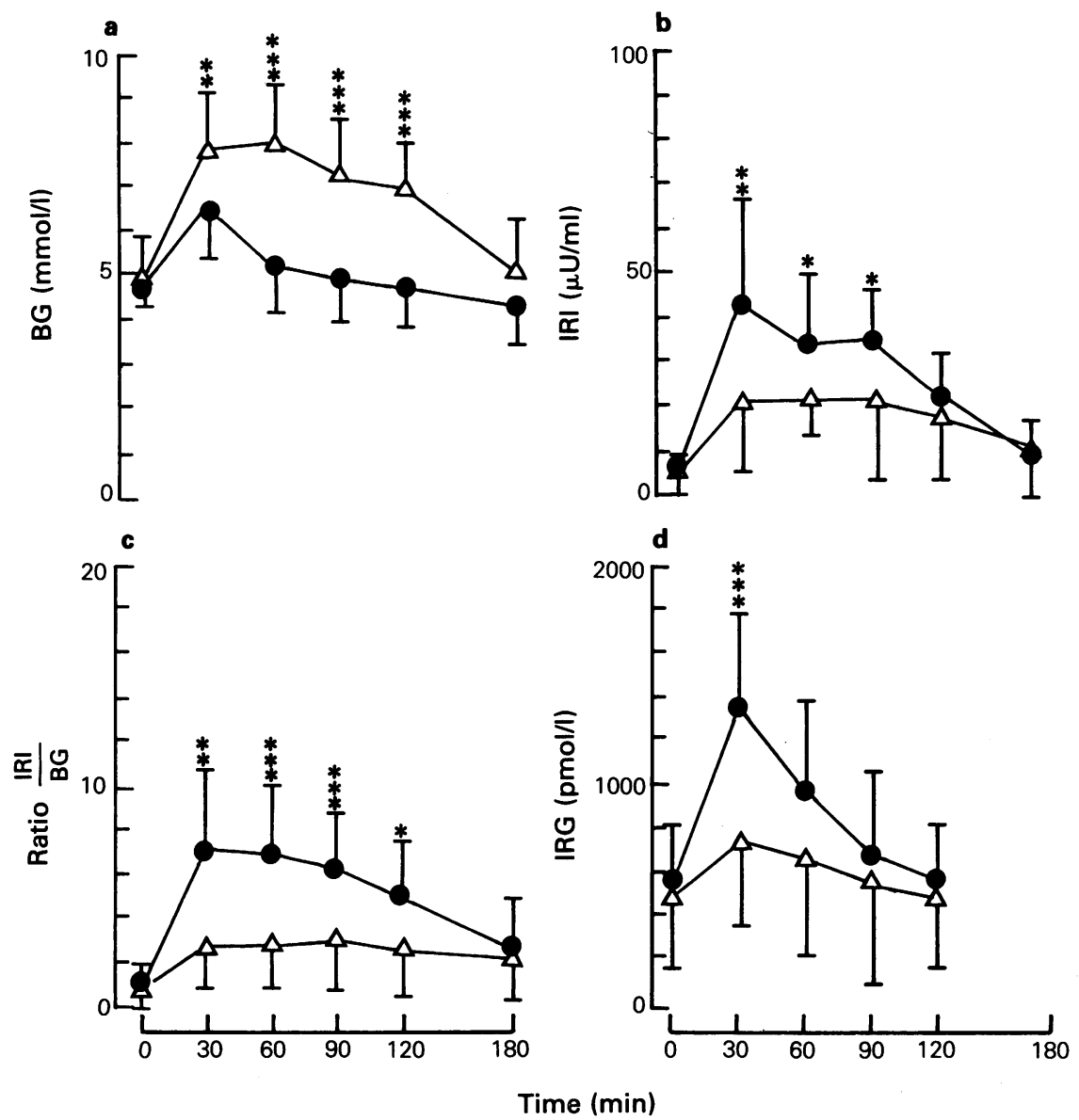

Figure 1 Mean ( \pm s.d.) levels of blood glucose (a; BG, mmol/l); plasma insulin (b; IRI, $\mu \mathrm{U} / \mathrm{ml}$ ); plasma insulin/ blood glucose ratio (c) and plasma glucagon (d; IRG, pmol/l) in normal controls (O) and patients with thalassaemia intermedia $(\Delta)$ during oral glucose tolerance test and arginine stimulation test. $P$ values: $*<0.05$; $* *<0.01 ; * * *<0.001$.

significantly different fasting but were significantly lower in the thalassaemic patients at 30,60 and $90 \mathrm{~min}$ following oral glucose (Table II, Figure 1). The sum of insulin concentrations obtained after OGTT, were significantly lower in thalassaemic patients than in the control group (thalassaemics: $108.1 \pm 82.4 \mu \mathrm{IU} / \mathrm{ml}$, controls: $160.5 \pm 46.2 \mu \mathrm{IU} / \mathrm{ml} ; P<0.05$ ).

In keeping with these findings, the insulin to glucose level ratio was significantly lower, during the 30 to 120 min time period, in the patients than in the controls (Figure 1). Compared with normals, fasting plasma glucagon concentrations were not significantly different in patients with thalassaemia intermedia, but were significantly lower in the thalassaemics at $30 \mathrm{~min}$ after ATT (Table III, Figure 1). The sum of glucagon concentrations, obtained after ATT, was significantly lower in thalassaemic patients than in the control
Table III Mean ( \pm s.d.) plasma glucagon (IRG) values before and during arginine stimulation test in patients with thalassaemia intermedia and in control subjects

\begin{tabular}{rlr}
\hline $\begin{array}{l}\text { Time } \\
(\text { min })\end{array}$ & \multicolumn{2}{c}{ IRG $(\mathrm{pmol} / \mathrm{l})$} \\
& \multicolumn{1}{c}{$(n=9)$} & $\begin{array}{c}\text { Controls } \\
(n=7)\end{array}$ \\
\hline 0 & $478.6 \pm 299.8$ & $575.9 \pm 224.4$ \\
30 & $747.3 \pm 382^{* * *}$ & $1372.8 \pm 407.1$ \\
60 & $663 \pm 401.2$ & $983.1 \pm 493.4$ \\
90 & $587.3 \pm 479.1$ & $703.3 \pm 375.4$ \\
120 & $501.5 \pm 366.8$ & $585.3 \pm 231$
\end{tabular}

Conversion: SI to traditional units $=$ glucagon $1 \mathrm{pmol} / / \approx$ $3.48 \mathrm{pg} / \mathrm{ml}$.

$* * *=P<0.01$ for the difference $v s$ the controls. 
group (thalassaemics $2898.6 \pm 1888.7 \mathrm{pmol} / 1$, controls $4205.5 \pm 1151.8 \mathrm{pmol} / \mathrm{l} ; P<0.05)$.

There was no demonstrable correlation between the sum of glucose concentrations and family history of diabetes mellitus or age, or between the sum of glucose, insulin and glucagon concentrations and serum ferritin.

\section{Discussion}

Patients affected by thalassaemia intermedia may have iron overload similar to that found in patients with transfusion dependent $\beta$ thalassaemia major (Pippard et al., 1979). In $\beta$ thalassaemia major abnormal glucose tolerance is well documented. The abnormality in carbohydrate metabolism ranges from impaired glucose tolerance in $30.8 \%$ in a group of thalassaemic subjects studied to frank diabetes in $8.9 \%$ of the patients (Capra et al., 1983). Glucose intolerance has been attributed to genetic factors (Saudek et al., 1977), to insulin resistance and hyperglucagonaemia secondary to cirrhosis (Costin et al., 1977), and to generalized islet cell injury from iron overload (Lassman et al., 1974).

In 1967, Bannerman et al. reported a 41 year old patient affected by $\beta$ thalassaemia intermedia with multiple endocrine disturbances, including diabetes mellitus. Recently, Vannaseng et al. (1981) demonstrated that mean basal and stimulated plasma insulin concentrations were low in response to oral glucose stimulation in $16 \beta$ thalassaemia/haemoglobin patients (aged 8-20y). Only one out of 16 had a diabetic glucose tolerance curve. Serum ferritin levels were not reported in these patients.

The role of glucagon secretion and its influence on glucose metabolism has not been studied before in patients with thalassaemia intermedia. Therefore, the aim of our study was to investigate the influence of alpha and beta cell secretion on carbohydrate metabolism in patients with thalassaemia intermedia and iron overload. Impaired glucose tolerance and grossly reduced insulin and glucagon secretion were found in three patients. However, a slight impairment of beta and alpha cell function, as demonstrated by low mean insulin and glucagon levels, after OGTT and ATT, was observed in all the patients who were studied. The absence of a correlation between the sum of glucose, insulin and glucagon concentrations and iron overload suggests that impaired glucose tolerance is not only due to iron deposition. The reduction of insulin secretion may be attributed to several factors. One of them is chronic hypoxia, since there is evidence that it might determine hypofunction of endrocrine glands (Zappulla et al., 1981). Defective release of gastrointestinal hormones is another factor which may be responsible or contribute to reduction of insulin response to glucose administration. This is suggested by the fact that, although lower than in controls, insulin response after intravenous glucose was higher than after oral glucose in 2 patients (nos. 2,6) out of 3 (nos. 2, 6, 7) in whom the intravenous test was done.

Increased production of catecholamines and zinc deficiency are other factors which can explain the reduced insulin response. Catecholamines inhibit insulin release (Wilber et al., 1966). Increased urinary vanillyl-mandelic acid excretion has been found in thalassaemic subjects by Matsaniotis et al. (1968). Zinc has been implicated in insulin metabolism (Chooi et al., 1976). Zinc deficiency in thalassaemic subjects has been found by Arcasoy \& Cavdar (1975) and has been confirmed by us in some intermediate thalassaemics (Di Palma et al., unpublished data).

The low glucagon levels after ATT found in our patients are comparable with those seen in cystic fibrosis (Lippe et al., 1973 and transfusional haemosiderosis (Lassman et al., 1974). It is likely that this altered pancreatic alpha cell response is secondary to both a combined toxic effect of iron overload and chronic hypoxia on pancreatic alpha cells. In view of metabolic antagonism of glucagon to insulin, a decreased glucagon secretion might have a protective role on glucose haemostasis in our patients. However, additional studies are needed to exclude an enhanced peripheral tissue sensitivity to insulin in these patients. It is not at present known whether the patients found to have abnormal glucose tolerance are at increased risk of developing diabetes, but it is hoped that a periodic assessment of glucose tolerance of these patients will provide this information in the future. In conclusion, our data emphasize the mildness of the carbohydrate defect as compared to the degree of insulinopenia. In addition the results indicate the necessity for prescribing measures which prevent excessive iron deposition and improve iron excretion in patients affected by thalassaemia intermedia.

\section{Acknowledgements}

We would like to thank Dr Beatrix Wonke for her encouragement and Mrs Nadia Baraldi and Natalina Capisani for secretarial assistance. This study was supported by the Italian Research Council (C.N.R.) no. 82.01119.83. 


\section{References}

ARCASOY, A. \& CADVAR, A.O. (1975). Changes of trace elements (serum iron, zinc, copper and magnesium) in thalassaemia. Acta haematologica, 53, 341.

ATTI, G., CAPRA, L., DE SANCTIS, V., VULLO, C. \& BAGNI, B. (1983). Beta-cell function assessed by plasma C-peptide evaluation in diabetic thalassaemic patients. Helvetica Paediatrica Acta, 38, 123.

BANNERMAN, R.M., KEUSCH, G., KREIMER-BIRNBAUM, M., VANCE, V.K. \& VAUGHAN, S. (1967). Thalassemia intermedia, with iron overload, cardiac failure, diabetes mellitus, hypopituitarism and porphyrinuria. American Journal of Medicine, 42, 476.

CAPRA, L., ATTI, G., DE SANCTIS, V. \& CANDINI, G.C. (1983). Glucose tolerance and chelation theraphy in patients with thalassaemia major Haematologica, 68, 63 .

CHOOI, M.K., TODD, J.K. \& BOYD, N. (1976). Influence of age and sex on plasma zinc levels in normal and diabetic individuals. Nutrition and Metabolism, 20, 135.

COSTIN, G., KOGUT, M.D., HYMAN, C. \& ORTEGA, J.A. (1977). Carbohydrate metabolism and pancretic islet-cell function in thalassaemia major. Diabetes, 26, 230.

DE ALARCON, P.A., DONOVAN, M.E., FORBES, J.B., LANDAW, S.A. \& STOKMAN, J.A. (1979). Iron absorption in the thalassaemia syndromes and its inhibition by tea. New England Journal of Medicine, 300, 5.

DE SANCTIS, V., ATTI, G., LUCCI, M., VULLO, C., BAGNI, B., GANDINI, G.C., CAVALLINI, A.R. \& SABATO, A. (1980). Endocrine assessment of hypogonadism in patients affected by thalassaemia major. La Ricerca Clinica $e$ di Laboratorio, 10, 663.

DILLON, R.S. \& MAWR, B. (1965). Importance of the hematocrit in interpretation of blood sugar. Diabetes, 14, 672.

EDITORIAL. (1980). Impaired glucose tolerance and diabetes - WHO criteria. British Medical Journal, 281, 1512.

ELLIS, J.T., SCHULMAN, I. \& SMITH, C.H. (1954). Generalized siderosis with fibrosis of liver and pancreas in Cooley's anemia, with observations on the pathogenesis of the siderosis and fibrosis. American Journal of Pathology, 30, 287.
FLYNN, M.D., FAIRNEY, A., JACKSON, T. \& CLAYTON, B.E. (1976). Hormonal changes in thalassaemia major. Archives of Disease in Childhood, 51, 828.

LASSMAN, M.N., GENEL, M., WISE, J.K., HENDERL, R. \& FELIG, P. (1974). Carbohydrate homeostasis and pancreatic islet cell function in thalassaemia. Annals of Internal Medicine, 80, 65.

LIPPE, B.M., SPERLING, M.A. \& DOOLEY, R.R. (1977). Pancreatic alpha and beta cell function in cystic fibrosis. Journal of Pediatrics, 90, 751.

MATSANIOTIS, N., BERATIS, N. \& ECONOMOU-MAVROUC, C. (1968). Urinary vanillyl-mandelic acid (VMA) excretion by chronically anaemic children. Archives of Disease in Childhood, 43, 372.

PIPPARD, M.J., CALLENDER, S.T., WAENER, G.T. \& WEATHERALL, D.J. (1979). Iron absorption and loading in $\beta$ thalassaemia intermedia. Lancet, ii, 819.

SABATO, A.R., DE SANCTIS, V., ATTI, G., CAPRA, L., BAGNI, B. \& VULLO, C. (1983). Primary hypothyroidism and low $\mathrm{T}_{3}$ syndrome in thalassaemia major. Archives of Disease in Childhood, 58, 120.

SAUDEK, C.D., HEMM, R.M. \& PETERSON, C.M. (1977). Abnormal glucose tolerance in $\beta$ thalassaemia major. Metabolism, 26, 43.

VANNASENG, S., PLOYBUTR, S., VISUTKUL, P., TANDHANAND, S., SUWANIK, R. \& WASI, P. (1981). Endocrine function in thalassaemia. Clinical Endocrinology, 14, 165.

WEATHERALL, D.J. \& CLEGG, J.B. (1972). In The Thalassaemia Syndromes. 2nd ed. Blackwell Scientific Publications: Oxford.

WILBER, J.F., TURTLE, J.R. \& CRANE, N.A. (1966). Inhibition of insulin secretion by a phaeocromocytoma. Lancet, ii, 733.

ZAPPULLA, F., BALSAMO, A., TASSINARI, D., MARSCIANI, A., BERGAMASCHI, R., BERNI, N. \& CACCIARI, E. (1981). Rapporto fra la funzione ipotalamoipofisi-gonadica ed il livello emoglobinico nel bambino talassemico politrasfuso. Minerva Pediatrica, 33, 317. 